\title{
PENGARUH EDUKASI GIZI TERHADAP PENGETAHUAN GIZI DAN ASUPAN ENERGI, PROTEIN DAN BESI PADA REMAJA
}

\author{
Asmarudin Pakhri, Sukmawati, Nurhasanah \\ Jurusan Gizi Politeknik Kesehatan Kemenkes Makassar
}

\begin{abstract}
ABSTRACK
Bad knowledge leads to nutritional problems. One of the efforts to improve the nutritional status of adolescents is by providing nutritional knowledge about balanced diet so they can achieve optimal health. This study aims to determine the effect of nutritional education on nutritional knowledge, energy, protein and iron intake of adolescents in SMP Negeri 35 Makassar. This research is Quasi Experimental with one pre-test and post-test group design. Samples are 34 students of class VIII selected by cluster random sampling. This study analyzed by paired sample t test. Nutrition education is given by lecture method and discussion using leaflet with frequency 3 times meeting in 3 weeks. The results showed that there is an effect of nutritional education on nutritional knowledge, energy and protein intake with $p$ value $=0,000, p=0,005$ and $p=0,002(\alpha<0,05)$, while there is no effect of nutritional education on iron intake With $p$ value $=0,555(\alpha>0,05)$. Nutritional education is useful in improving nutritional knowledge, energy and protein intake.
\end{abstract}

Keywords : Nutritional education, energy, protein, iron intake.

\section{PENDAHULUAN}

Remaja termasuk golongan rentan terhadap masalah gizi karena berbagai sebab yaitu, pertama, remaja memerlukan zat gizi yang lebih tinggi karena peningkatan pertumbuhan fisik kognitif, dan psikososial. Kedua, adanya perubahan gaya hidup dan kebiasaan makan remaja akan mempengaruhi baik asupan maupun kebutuhan gizinya. Ketiga, remaja yang mempunyai kebutuhan gizi khusus seperti remaja yang aktif dalam kegiatan olahraga, sedang hamil, menderita penyakit kronis, melakukan diet secara berlebihan, pecandu alkohol atau obat-obatan terlarang (Almatsier, 2010).

Berdasarkan data Studi Diet Total (SDT) 2014, rata-rata asupan energi dan protein penduduk menurut kelompok umur dan jenis kelamin penduduk Sulawesi Selatan menunjukkan rerata kecukupan asupan energi per orang per hari terendah pada kelompok usia 13-18 tahun (usia remaja) dibandingkan kelompok usia lainnya dengan 71,7\% AKE. Sedangkan rerata kecukupan asupan protein per orang per hari, terendah pada kelompok usia 13-18 tahun (usia remaja) dibandingkan kelompok usia lainnya dengan 93,5\% AKP (Siswantoro dkk, 2014).

Penelitian lain oleh Hatta (2014) mengenai gambaran asupan energi dan protein serta status gizi pada siswa SMP Negeri 35 Makassar menunjukkan bahwa terdapat $76,7 \%$ siswa yang memiliki konsumsi energi kurang dan 63,3\% siswa yang memiliki konsumsi protein kurang. Hal ini didukung oleh penelitan Novitasari (2014) pada remaja di Kota Surakarta menunjukkan bahwa terdapat $43,5 \%$ siswa memiliki asupan protein kurang, dan sebesar 73,9\% siswa memiliki konsumsi zat besi kurang. Penelitian Hendrayati, dkk, 2010 di SMP Tompobulu Bantaeng mendapatkan asupan energi dan pola makan siswa sebagian masih kurang (52,1\% dan 96,9\%).

Pada masa remaja, kebutuhan energi dan protein meningkat untuk memenuhi kebutuhan untuk pertumbuhan cepat. Jika asupan energi tidak terpenuhi, protein digunakan untuk memenuhi kebutuhan energi namun tidak ada persediaan untuk sintesis jaringan baru atau untuk perbaikan jaringan yang rusak. Keadaan ini dapat menyebabkan penurunan tingkat pertumbuhan dan massa otot meskipun konsumsi protein cukup (Almatsier dkk, 2011). Menurut data Riskesdas 2013 sebagian remaja mengalamai kurang gizi dimana prevalensi yang pendek dan sangat pendek $35 \%$ serta yang kurus dan sangat kurus $11 \%$. Disamping itu sebagian remaja kelebihan gizi yaitu 10,8\% gemuk dan sangat gemuk (Balitbangkes, 2013).

Proverawati dan Kusuma (2011) menyebutkan bahwa remaja selain membutuhkan energi dan protein lebih banyak, juga membutuhkan zat besi lebih banyak. Kebutuhan zat besi pada remaja meningkat karena terjadinya pertumbuhan cepat. Kebutuhan zat besi pada remaja laki-laki meningkat karena ekspansi volume darah dan peningkatan konsentrasi hemoglobin $(\mathrm{Hb})$, pada perempuan kebutuhan zat besi yang tinggi terutama disebabkan kehilangan zat besi selama menstruasi.

Arisman (2010) menyebutkan bahwa salah satu penyebab masalah gizi dikarenakan minimnya pengetahuan akan gizi yang kemudian dapat menyebabkan kesalahan dalam memilih makanan. Kebiasaan makan remaja yang kurang baik bermula pada kebiasaan makan keluarga yang juga kurang baik dan sudah tertanam sejak kecil dan akan terus terjadi pada usia remaja. Mereka makan seadanya tanpa mengetahui kebutuhan berbagai zat gizi dan dampak tidak dipenuhinya kebutuhan zat gizi tersebut terhadap kesehatan mereka. Kebiasaan makan pada masa remaja akan berdampak terhadap kesehatan pada fase kehidupan selanjutnya.

Faktanya hasil penelitian menunjukkan pengetahuan gizi remaja sebagian masih kurang. Penelitian Achmad, dkk (2014) di Makassar mendapatkan lebih separoh pengetahuan gizi remaja masih kurang yaitu 58,5 \% pada pelajar 
SMAN 10 dan 53,1\% SMAN 16 Makassar. Demikian juga penelitian Afdal tahun 2011 di SMPN 1 Sawahlunto mendapatkan pengetahuan gizi siswa 51,9\% masih kurang.

Untuk mempebaiki asupan gizi dan status gizi remaja antara lain perlu upaya peningkatan pengetahuan gizi melalui pendidikan gizi. Upaya pendidikan gizi melalui penyuluhan dengan media buku saku selama seminggu pada siswa kelas XI SMA Semarang berhasil meningkatkan pengetahuan gizi dan asupan energi dan protein (Sefaya, dkk, 2017).

Berdasarkan hal tersebut, penulis tertarik untuk meneliti tentang pengaruh edukasi gizi terhadap pengetahuan gizi, asupan energi, protein, dan zat besi pada remaja di SMP Negeri 35 Makassar.

\section{METODE PENELITIAN}

Penelitian ini merupakan penelitian Quasi Eksperimen dengan rancangan one group pre-test and post-test design. Penelitian ini dilaksanakan di SMP Negeri 35 Makassar pada bulan Februari Juni 2017. Populasi dalam penelitian ini adalah seluruh siswa/siswi kelas VIII sebanyak 297 orang, dengan sampel sebanyak 34 orang yang dipilih berdasarkan cluster random sampling. Intervensi yang dilakukan berupa edukasi gizi dengan metode ceramah dan diskusi dengan alat bantu media leaflet dengan frekuensi 3 kali pertemuan dalam 3 minggu.

Metode pengumpulan data pengetahuan dengan kuesioner isian dan data asupan energi, protein dan zat besi dengan metode recall $2 \times 24$ jam. Pengumpulan data dilakukan sebelum dan sesudah diberikan intervensi. Pengolahan data diinput ke dalam komputer dan dianalisis menggunakan program SPSS. Pengaruh edukasi gizi terhadap pengetahuan gizi, asupan energi, protein, dan zat besi pada remaja di analisis dengan menggunakan Uji t dua sampel berpasangan dengan $\alpha<0,05$.

\section{HASIL}

\section{Karakteristik Sampel}

Hasil penelitian menunjukkan umumnya sampel berjenis kelamin perempuan sebanyak $73,5 \%$ dan laki-laki 9 orang $(26,5 \%)$. Umur sampel 14 tahun sebanyak 25 orang $(52,9 \%)$ dan. 13 tahun sebanyak $47,1 \%$. Karakteristisk orang tua sampel, pekerjaan ayah umumnya adalah karyawan swasta sebanyak $70,6 \%$ dan pekerjaan ibu umumnya adalah Ibu rumah tangga sebanyak 67,6\%. Pendidikan orang tua sampel baik ayah maupun ibu pada umumnya tamat perguruan tinggi yang disajikan pada tabel 1 .

Tabel 1

Karakteristik Orang Tua Sampel

\begin{tabular}{lcccc}
\hline \multicolumn{1}{r}{ Karakteristik } & Ayah & & Ibu & \\
\hline \hline & n & \% & N & \% \\
\hline Pekerjaan & & & & \\
PNS & 6 & 17,6 & 10 & 29,4 \\
Karyawan swasta & 24 & 70,6 & 1 & 2,4 \\
Buruh & 1 & 2,9 & 0 & 0 \\
Pensiuan & 3 & 8,8 & 0 & 0 \\
Tidak bekerja & 0 & 0 & 23 & 67,6 \\
Jumlah & 34 & 100 & 34 & 100 \\
\hline Pendidikan & & & & \\
SMA & 8 & 23,5 & 15 & 44,1 \\
Perguruan Tinggi & 26 & 76,5 & 19 & 55,9 \\
Jumlah & 34 & 100 & 34 & 100 \\
\hline
\end{tabular}

\section{Pengetahuan Gizi Sebelum dan Sesudah Edukasi Gizi \\ Hasil penelitian menunjukkan bahwa} sampel yang memiliki tingkat pengetahuan gizi baik sebelum diberikan edukasi gizi yaitu sebesar
$32,4 \%$, dan yang tergolong kurang sebesar $67,6 \%$. Sedangkan tingkat pengetahuan gizi baik setelah edukasi gizi yaitu sebesar $97,1 \%$, dan yang tergolong kurang yaitu sebesar $2,9 \%$ yang disajikan pada tabel 2 . 
Tabel 2

Pengetahuan Gizi Siswa Sebelum dan Sesudah Edukasi Gizi

\begin{tabular}{ccccc}
\hline \hline Pengetahuan & \multicolumn{2}{c}{ Sebelum } & \multicolumn{3}{c}{ Sesudah } \\
\cline { 2 - 5 } Gizi & $\mathbf{n}$ & $\mathbf{0}$ & $\mathbf{N}$ & $\mathbf{\%}$ \\
\hline Kurang & 23 & 67,6 & 33 & 2,9 \\
Baik & 11 & 32,4 & 34 & 97,1 \\
\hline Jumlah & 34 & 100 & 100 \\
\hline
\end{tabular}

\section{Asupan Energi, Protein dan Zat Besi}

Hasil penelitian menunjukkan bahwa sampel yang memiliki tingkat asupan baik sebelum edukasi gizi yaitu energi sebesar $47,1 \%$, protein
$55,9 \%$ dan zat besi $0 \%$. sedangkan sampel yang memiliki tingkat asupan baik setelah edukasi gizi yaitu energi sebesar $52,9 \%$, protein $82,4 \%$ dan zat besi $0 \%$ yang disajikan pada tabel 3 .

Tabel 3

Asupan Gizi Siswa Sebelum dan Sesudah Edukasi Gizi

\begin{tabular}{|c|c|c|c|c|}
\hline \multirow{2}{*}{ Asupan } & \multicolumn{2}{|c|}{ Sebelum } & \multicolumn{2}{|c|}{ Sesudah } \\
\hline & $\mathbf{n}$ & $\%$ & $\mathbf{N}$ & $\%$ \\
\hline \multicolumn{5}{|l|}{ Energi } \\
\hline Kurang & 18 & 52,9 & 16 & 47,1 \\
\hline Baik & 16 & 47,1 & 18 & 52,9 \\
\hline \multicolumn{5}{|l|}{ Protein } \\
\hline Kurang & 15 & 44,1 & 6 & 17,6 \\
\hline Baik & 19 & 55,9 & 28 & 82,4 \\
\hline \multicolumn{5}{|l|}{ Zat Besi } \\
\hline Kurang & 34 & 100 & 34 & 100 \\
\hline Baik & 0 & 0 & 0 & 0 \\
\hline Jumlah & 34 & 100 & 34 & 100 \\
\hline
\end{tabular}

\section{Pengaruh Edukasi Gizi Terhadap Pengetahuan} Gizi

Hasil penelitian menunjukkan bahwa ada perubahan rata-rata pengetahuan gizi sebelum dan sesudah edukasi gizi. Hasil uji T test menunjukkan ada pengaruh yang bermakna dimana nilai $\mathrm{p}=$ $0,000(\alpha<0,05)$.

Tabel 4

Pengaruh Edukasi Gizi Terhadap Pengetahuan Gizi Siswa

\begin{tabular}{ccccc}
\hline \hline \multirow{2}{*}{ Variabel } & \multirow{2}{n}{} & \multicolumn{2}{c}{ Rata-rata \pm SD } & \multirow{2}{*}{$\boldsymbol{p}$} \\
\cline { 3 - 4 } & & Sebelum & Sesudah & \\
\hline Pengetahuan & 34 & $7,9 \pm 1,1$ & $11,2 \pm 1,2$ & 0,000 \\
\hline
\end{tabular}

\section{Pengaruh Edukasi Gizi Terhadap Pengetahuan} Gizi

Hasil penelitian menunjukkan bahwa ada perubahan rata-rata asupan energi sebelum dan sesudah edukasi gizi. Hasil uji T test menunjukkan ada pengaruh yang bermakna dimana nilai $\mathrm{p}=$ $0,005(\alpha<0,05)$. Perubahan rata-rata asupan protein sebelum dan sesudah edukasi gizi menunjukkan ada pengaruh yang bermakna dengan $\alpha<0,05(\mathrm{p}=0,002)$. Sedangkan hasil uji $\mathrm{T}$ test asupan zat besi menunjukkan tidak adanya pengaruh yang signifikan sebelum dan sesudah edukasi gizi dimana nilai $p=0,555(\alpha>0,05)$. 
Tabel 5

Pengaruh Edukasi Gizi Terhadap Asupan Gizi Siswa

\begin{tabular}{ccccc}
\hline \hline Variabel & \multirow{2}{*}{ R } & \multicolumn{2}{c}{ Rata-rata \pm SD } & \multirow{2}{*}{ SD } \\
\cline { 3 - 4 } Asupan & & Sebelum & Sesudah & 0,005 \\
Energi & 34 & $1650,5 \pm 360,7$ & $1767,2 \pm 1,2$ & 0,002 \\
Protein & 34 & $59,1 \pm 12,2$ & $64,1 \pm 9,9$ & 0,002 \\
Zat Besi & 34 & $6,2 \pm 2,0$ & $6,0 \pm 1,5$ & 0,555 \\
\hline
\end{tabular}

\section{PEMBAHASAN}

\section{Pengaruh Edukasi Gizi Terhadap Pengetahuan} Gizi

Hasil penelitian menunjukkan bahwa ada perubahan rata-rata pengetahuan gizi sebelum dan sesudah edukasi gizi. Hasil uji T test menunjukkan ada pengaruh yang bermakna dimana nilai $p=$ $0,000(\alpha<0,05)$.

Hasil penelitian ini sejalan dengan penelitian yang dilakukan oleh Rachmawati dan Nurafifah (2014) yang menunjukkan adanya pengaruh penyuluhan gizi terhadap pengetahuan gizi responden, terbukti dengan adanya nilai signifikansi $(p)$ sebesar 0,000. Demikian juga pendidikan gizi yang dilakukan Sefaya, dkk (2017) pada siswa SMA di Semarang dengan media buku saku berhasil meningkatkan pengetahuan gizi siswa.

Hal tersebut disebabkan karena perlakuan yang diberikan berupa edukasi gizi dengan materi masalah gizi remaja dan upaya pemenuhan kebutuhan energy, protein dan zat besi remaja berhasil dipahami mereka. Penggunaan media leaflet membantu pemahaman materi yang diberkan. Seperti yang dikemukakan oleh Notoatmodjo (2007), metode pendidikan gizi dapat dilakukan dengan berbagai cara salah satunya dengan metode pendidikan kelompok melalui ceramah dan diskusi, dengan memberikan pendidikan kesehatan secara intensif serta dibantu media dapat menghasilkan perubahan dan peningkatan pengetahuan pada individu, maupun kelompok.

Menurut Proverawati dan Kusuma (2011), tujuan akhir dari pendidikan gizi yang diberikan kepada remaja yakni dapat mengubah sikap dan tindakan kearah kesadaran untuk melakukan pemenuhan kebutuhan gizi agar hidupnya sehat.

\section{Pengaruh Edukasi Gizi Terhadap Asupan Energi, Protein dan Zat Besi}

Hasil penelitian menunjukkan bahwa ada perubahan rata-rata asupan energi dan protein sebelum dan sesudah edukasi gizi. Hasil uji T test menunjukkan ada pengaruh yang bermakna sebelum dan sesudah edukasi gizi terhadap asupan energi dimana nilai $p=0,005(\alpha<0,05)$, dan ada pengaruh yang bermakna sebelum dan sesudah edukasi gizi terhadap asupan protein dimana nilai $p$ $=0,002(\alpha<0,05)$.
Hasil penelitian ini sejalan dengan penelitian yang dilakukan oleh Widhayati (2009) yang menunjukkan bahwa sesudah pendidikan gizi ada pengaruh pada tingkat kecukupan energi antara grup kelompok dan individu $(p=0,036)$. Sedangkan berdasarkan penelitian Nurmasyita,dkk (2015) menyatakan terdapat perbedaan rerata tingkat kecukupan protein yang menunjukkan adanya pengaruh yang bermakna sebelum dan sesudah intervensi dimana $p=0,030(\alpha<0,05)$. Ini menunjukkan bahwa pendikan gizi yang diberikan selain meningkatkan pengetahuan juga telah dipraktekkan dalam pemenuhan kebutuhan energi dan proteinnya.

Sedangkan hasil uji T test asupan zat besi menunjukkan tidak adanya pengaruh yang signifikan sebelum dan sesudah edukasi gizi dimana nilai $p=0,555(\alpha>0,05)$. Hal ini sesuai dengan hasil penelitian Sefaya, dkk, (2017) pada siswa SMA Semarang yang menunjukkan pendidikan gizi tidak berpengaruh pada konsumsi zat besi. Namun berbeda dengan hasil penelitian Marfuah dan Kusudaryati (2016), yang menunjukkan bahwa pemberian edukasi gizi efektif meningkatkan rata-rata asupan zat besi pada remaja putri dengan $p=0,000(\alpha<0,05)$.

Hasil penelitian tersebut dapat disebabkan karena pemilihan bahan makanan yang dikonsumsi sampel kurang bervariasi seperti yang tergambar pada recall 24 jam yang dilakukan menunjukkan bahwa pada saat mereka mengonsumsi lauk nabati (tahu dan tempe), mereka tidak lagi mengonsumsi lauk hewani, dan sebagian besar sampel tidak mengonsumsi sayuran hijau yang kaya akan zat besi. Penyebab lain yaitu adanya remaja yang hanya menyukai makanan tertentu yang menyebabkannnya tidak mendapatkan asupan gizi yang bervariasi. Ketidakberagaman makanan yang dikonsumsi dapat menyebabkan ketidakcukupan asupan gizi termasuk zat besi yang akhirnya dapat memicu terjadinya produksi sel darah merah, yang kemudian dapat menyebabkan anemia (Fitriani, 2015).

\section{KESIMPULAN}

1. Pengetahuan gizi sebelum diberi edukasi gizi yaitu yang tergolong baik sebesar $32,4 \%$, dan setelah edukasi gizi yaitu $97,1 \%$. 
2. Asupan energi dan protein sebelum diberi edukasi gizi yaitu yang tergolong baik sebesar $47,1 \%$ dan $55,9 \%$, setelah edukasi gizi menjadi $52,9 \%$ dan $82,4 \%$. Sedangkan pada asupan zat besi tidak terjadi peningkatan asupan setelah diberi edukasi gizi dimana $100 \%$ sampel tetap tergolong kurang asupan zat besi.

3. Ada pengaruh edukasi gizi terhadap pengetahuan gizi sebelum dan sesudah intervensi dengan nilai nilai $p=0,000(\alpha<$ $0,05)$.

4. Ada pengaruh edukasi gizi terhadap asupan energi dan protein sebelum dan sesudah intervensi dengan nilai $p=0,005$ dan $p=0,002$ $(\alpha<0,05)$. Sedangkan pada asupan zat besi menunjukkan tidak adanya pengaruh yang signifikan sebelum dan sesudah edukasi gizi dimana nilai $p=0,555(\alpha>0,05)$.

\section{SARAN}

\begin{abstract}
Untuk memperbaiki kebiasaan makan para remaja sebaiknya instansi berwenang memprogramkan edukasi gizi dengan melengkapi media yang diperlukan sehingga diperoleh kualitas generasi yang lebih produktif dan akan melahirkan anak yang berkualitas. Bagi peneliti selanjutnya diharapkan dapat memberikan pendidikan menggunakan media lainnya dengan frekuensi yang lebih sering, dan sasaran yang lebih luas misalnya orang tua dan pengelola kantin yang menyediakan makanan bagi remaja.
\end{abstract}

\section{DAFTAR PUSTAKA}

Almatsier, Sunita. (2010). Prinsip dasar Ilmu Gizi. Jakarta: PT. Gramedia Pustaka Utama.

Almatsier, S, Soetardjo, S, dan Soekatri, M. (2011). Gizi Seimbang Dalam Daur Kehidupan. Jakarata: PT. Gramedia Pustaka Utama.

Arisman, MB. (2010). Gizi Dalam Daur Kehidupan. Jakarta: EGC.

Balitbangkes 2013. Hasil Riset Kesehatan Dasar 2013. Kemenkes RI Jakarta.

Fitriani. (2015). Promosi Kesehatan. Yogyakarta: Graha Ilmu.

Hatta, Fitriana. (2014). Gambaran Asupan Energi dan Protein Serta Status Gizi Pada Siswa SMPN 35 Kelas VII Prasejahtera di Kecamatan Biringkanaya Kota Makassar. Karya Tulis Ilmiah. Politeknik Kesehatan Makassar.

Hendayati, Salmiah dan Suriani Rauf, 2010. Pengetahuan Gizi, Pola Makan dan Status Gizi Siswa SMPN Tompobulu Bantaeng.
Media Gizi Pangan, Vol IX, Ed 1, Jan-Juni 2010. P33-40

Marfuah, Dewi dan Kusudaryati, Dewi Pertiwi Dyah. (2016). Efektifitas Edukasi Terhadap Perbaikan Asupan Zat Besi Pada Remaja Putri. Jurnal. Vol 14 (1). Prodi S1 Ilmu Gizi STIKES PKU Muhammadiyah Surakarta.

Notoatmodjo, Soekidjo. (2007). Kesehatan Masyarakat Ilmu Dan Seni. Jakarta: PT. Rineka Cipta.

Novitasari, Suci. (2014). Hubungan Tingkat Asupan Protein, Zat Besi, Vitamin C, dan Seng dengan Kadar Hemoglobin Remaja Putri Di SMA Batik 1 Surakarta. Karya Tulis Ilmiah. Program Studi Diploma III Gizi Fakultas Ilmu Kesehatan Universitas Muhammadiyah Surakarta.

Nurmasyita, Widjanarko, Bagoes dan Margawati, Ani. (2015). Pengaruh Intervensi Pendidikan Gizi Terhadap Pengetahuan Gizi, Perubahan Asupan Zat Gizi dan Indeks Massa Tubuh Remaja Kelebihan Berat Badan. Jurnal Gizi Indonesia. Vol 4 (1): 38-47.

Proverawati, Atikah dan Kusuma, Erna Wati. (2011). Ilmu Gizi Untuk Keperawatan \& Gizi Kesehatan. Yogyakarta: PT Nuha Medika.

Rachmawati, M dan Nurafifah (2014). Pengaruh Pemberian Penyuluhan Gizi Terhadap Pengetahuan Gizi Dan Sikap Hidup Sehat Remaja Di Sekolah Menengah Atas Negeri 2 Sidoarjo. Ejurnal Boga. Vol 03 (3). Program Studi S1 Fakultas Teknik Universitas Negeri Surabaya.

Sefaya, K,T; Nugraheni dan Dina Rahayuning, 2017. Pengaruh Pendidikan Gizi Terhadap Pengetahuan Gizi dan tingkat Kecukupan Gizi Terkait Pencegahan Anemia Remaja. Jurnal Kes.Masy. (ejournal) Vol 5 No. 1, Jan $2017 \quad$ (http://ejournals1.undip.ac.id/index.php/jkm)

Siswantoro, Hadjar, dkk. (2014). Buku Studi Diet Total Survei Konsumsi Makanan Individu Provinsi Sulawesi Selatan 2014. Jakarta: Badan Penelitian dan Pengembangan Kesehatan.

Widhayati, Retno Endah. (2009). Efek Pendidikan Gizi Terhadap Perubahan Konsumsi dan Indeks Massa Tubuh Pada Remaja Kelebihan Berat Badan. Tesis. Program Pascasarjana Universitas Diponegoro Semarang. 